\title{
Feedlot of lambs fed biodiesel co-products: performance, commercial cuts and economic evaluation
}

\author{
Eliéder Prates Romanzini ${ }^{1}$ - Américo Garcia da Silva Sobrinho ${ }^{1}$. \\ Roberta de Lima Valença $^{1}$ - Thiago Henrique Borghi ${ }^{1}$ - Nomaiací de Andrade ${ }^{1}$. \\ Priscila Arrigucci Bernardes ${ }^{2}$
}

Received: 22 June 2017 / Accepted: 19 September 2017 / Published online: 23 September 2017

(C) Springer Science+Business Media B.V. 2017

\begin{abstract}
The aim of this study was to evaluate the animal performance, commercial cuts, and their yields within the production system, and economics of sheep production, of lambs finished in feedlots and fed with or without biodiesel co-products. A total of 40 lambs were divided into four biodiesel co-product treatment groups: a no-treatment control; peanut meal; crude glycerin; and peanut meal + crude glycerin. Animal performance did not differ $(P>0.05)$ among the treatment groups, where the average daily gain was close to $0.26 \mathrm{~kg} /$ day. Likewise, the quantitative carcass characteristics did not differ $(P>0.05)$ and the biological mean yield was $54.92 \%$. Similarly, the commercial cuts and their yields did not differ $(P \geq 0.09)$ among the treatments. These results took into consideration the standard, age, and slaughter body weight of the animals. The economic evaluation determined that peanut meal was the best co-product for use in finishing lambs in a feedlot. Hence, all the biodiesel co-products evaluated can be used at feedlots to finish lambs without changing the variables measured.
\end{abstract}

Keywords Crude glycerin $\cdot$ Partial budgets $\cdot$ Peanut meal

Eliéder Prates Romanzini

elieder.romanzini@gmail.com

1 Department of Animal Science, School of Agricultural and Veterinarian Sciences, São Paulo State University (Unesp), Jaboticabal, SP, Brazil

2 Department of Exact Science, School of Agricultural and Veterinarian Sciences, São Paulo State University (Unesp), Jaboticabal, SP, Brazil

\section{Introduction}

The current world scenario concerning the environment is the negative effects of climate change, which have caused innumerous problems within the agricultural system. The main problem is interrelated with the trend in decreasing rain quantity that will eventually reduce annual agricultural production globally (Myers et al. 2017). Considering the relationship between agriculture and livestock, it is feasisble to say that livestock production will be negatively affected by such reductions as well. Given that population growth is only increasing worldwide, the pressure to achieve the best results in livestock and agricultural practices is constant and ever-demanding.

To increase the supply of food for humans, it is important that distinct species ingest diverse kinds of food. Therefore, the diet of animals destined for human consumption should be changed in such a way so as to improve the sources of protein and energy for the human diet due to the higher grain and animal proteins available. One way to feed animals with other kinds of diets is to use agroindustry co-products. Nowadays, many kinds of meals, seeds, and other products result from daily manufacturing.

Glycerin is a co-product of biodiesel production from vegetable oils and can be used to replace corn grain as an energy ingredient in animal nutrition (Ezequiel et al. 2015). Another co-product of biodiesel production is peanut meal (PM), a residue from oil extraction. PM is a great protein source and could replace soybean meal in animal diets. These replacements would result in higher food quantities for humans. The quantities of such co-products for use in animal diets are increasing annually; for example, each biodiesel unit produced results in 10\% of glycerin (Oliveira et al. 2013). Consequently, the potential environmental problems caused by overproduction of these co-products can be resolved by redirecting them for use in animal nutrition. 
Several authors have evaluated the effects of replacement levels of agroindustry co-products on the performance and commercial cuts of lamb (Ružić-Muslić et al. 2014; Merlim et al. 2015), and although none of them reported negative results in this regard, those researchers did not evaluate a simultaneous replacement of protein and energetic ingredients. Hence, the aim of this current study was to evaluate the economic viability and effects of dietary replacements of corn grain and soybean meal (traditional ingredients) with crude glycerin (CG) and PM (biodiesel co-products) on the animal performance and commercial cuts and yields of lambs finished in feedlots. Our hypothesis is that replacement of the traditional ingredients by biodiesel co-products would not alter the performance and results (commercial cuts and economics) for Ile de France lambs finished in feedlots.

\section{Materials and methods}

The experiment was developed at the School of Agricultural and Veterinarian Sciences-Unesp (Campus Jaboticabal, Brazil), located at $21^{\circ} 14^{\prime} \mathrm{S}, 48^{\circ} 17^{\prime} \mathrm{W}$; elevation $615 \mathrm{~m}$.

The experimental diets evaluated in trials (Table 1) were formulated according to National Research Council guidelines (NRC 2006) for weaned lambs, for an average weight gain of $300 \mathrm{~g} /$ day. The roughage-to-concentrate ratio was 40:60 in all diets, with treatments consisting of roughage + concentrate only (Control group), roughage + concentrate with PM at $20 \%$ dry matter (DM) (PM20 group), roughage + concentrate with CG at $25 \% \mathrm{DM}$ (CG25 group), and roughage + concentrate with $\mathrm{PM}$ at $10 \% \mathrm{DM}$ and CG at $12.5 \% \mathrm{DM}$ (PMCG group). The diets were supplied to the animals in a total mix ratio and had similar quantities of nitrogen (crude protein $(\mathrm{CP})$ $\sim 17 \%$ ) and metabolizable energy ( $\mathrm{ME} \sim 11.30 \mathrm{MJ} / \mathrm{kg} \mathrm{DM}$ ).

Samples of the diets and feed refusals obtained from the performance trial were oven-dried at $55{ }^{\circ} \mathrm{C}$ for $72 \mathrm{~h}$ and then ground through a Willey mill with a 1-mm sieve. Thereafter, they were stored and later analyzed to determine the DM, mineral matter, and ether extract according to methods 934.01, 942.05, and 920.39, respectively, of the Association of Official Analytical Chemists (AOAC 1995). The nitrogen concentration was determined using a LECO FP-528 nitrogen analyzer (LECO Corp., St. Joseph, MI, USA). The metabolizable energy was calculated after determining the crude energy in an adiabatic bomb calorimeter (Anton Paar GmbH, Graz, Austria) (Sniffen et al. 1992; NRC 2006).

The neutral detergent fiber was determined using $\alpha$ amylase and without the addition of sodium sulfite according to Van Soest (1994), in a method adapted for the Ankom ${ }^{200}$ Fiber Analyzer (Ankom Technology, Fairport, NY, USA). The acid detergent fiber was determined using the method described by Goering and Van Soest (1970), adapted for the Ankom ${ }^{200}$ Fiber Analyzer.
Table 1 Composition and nutritive value of the experimental diets

\begin{tabular}{lllll}
\hline Variable & \multicolumn{2}{l}{ Diet } & & \\
\cline { 2 - 5 } & Control & PM20 & CG25 & PMCG \\
\hline Composition (\%) & & & & \\
$\quad$ Corn silage & 40.00 & 40.00 & 40.00 & 40.00 \\
Crude glycerin ${ }^{1}$ & - & - & 25.00 & 12.50 \\
Peanut meal & - & 20.00 & - & 10.00 \\
Soybean meal & 21.00 & - & 32.35 & 16.00 \\
Corn grain & 36.25 & 37.00 & - & 18.66 \\
Dicalcium phosphate & 1.45 & 1.90 & 1.50 & 1.70 \\
Limestone & 0.30 & 0.10 & 0.15 & 0.14 \\
Premix & 1.00 & 1.00 & 1.00 & 1.00 \\
Chemical analyses (g/kg DM) & & & & \\
Dry matter (DM) & 654 & 662 & 654 & 658 \\
Organic matter (OM) & 936 & 939 & 923 & 931 \\
Crude protein (CP) & 174 & 178 & 173 & 175 \\
Ether extract (EE) & 40 & 39 & 18 & 29 \\
Mineral matter (MM) & 64 & 61 & 77 & 69 \\
Neutral detergent fiber (NDF) & 264 & 302 & 214 & 258 \\
Acid detergent fiber (ADF) & 149 & 165 & 131 & 148 \\
Nutritional value & & & & \\
Metabolizable energy & 11.72 & 11.46 & 11.05 & 11.21 \\
(MJ/kg DM) & & & & \\
\hline
\end{tabular}

Control: roughage + concentrate; PM20: roughage + concentrate with peanut meal 20\% DM; CG25: roughage + concentrate with crude glycerin 25\% DM; PMCG: roughage + concentrate with peanut meal 10\% and crude glycerin $12.5 \% \mathrm{DM}$

${ }^{1}$ Glycerol 83.9\%; moisture $12.01 \%$; salts $3.79 \%$; and pH 6.88

${ }^{2} \mathrm{ME}=0.82 * \mathrm{DE}$ (degradable energy) (Sniffen et al. 1992; NRC 2006)

A total of 40 non-castrated Ile de France lambs $(17.15 \pm 1.56 \mathrm{~kg}$ initial body weight) were used. When the lambs were about 60 days old, they were weaned and allocated to individual pens. Each pen was of $1.0 \mathrm{~m}^{2}$ area and had an individual water drinker and feeder. During the weaning process, the lambs were identified, dewormed, vaccinated against clostridiosis, supplemented with Fe and vitamins A, D, and E, and distributed randomly to the treatments.

To evaluate the individual dry matter intake (DMI), we used three measurement units: kilograms per day $(\mathrm{kg} /$ day), grams per kilo of metabolic weight per day $\left(\mathrm{g} / \mathrm{kg}^{0.75} /\right.$ day), and percentage of body weight $(\% \mathrm{BW})$. The DMI was calculated daily as the difference between the total diet supplied and the quantity of refusals weighed every morning before total mix ratio distribution. The individual BW was registered and monitored weekly. The average daily gain (ADG; g/day) was calculated per week and an average value was finally considered for each treatment. After these determinations, the feed conversion (FC) was calculated from the ratio between the total DMI and BW gain. 
Once the animals had reached $32.5 \pm 0.7 \mathrm{~kg} \mathrm{BW}$, they were fasted for $16 \mathrm{~h}$ and then slaughtered on different days, following the methods of Welfare Animal, where the animals were rendered unconscious by electric shock and bled. The lambs were weighed again to obtain the slaughter body weight (SBW) and to determine losses caused by fasting (LF). After bleeding, skinning, and gutting of the carcasses, both the full and empty gastrointestinal tracts (EGT) were weighed to obtain the weight of gastric contents and the empty body weight (EBW). After this, the carcasses were weighed to measure the hot carcass weight, which was used to determine the hot carcass yield (Castro et al. 2017). The carcasses were then chilled at $6{ }^{\circ} \mathrm{C}$ for $24 \mathrm{~h}$, after which they were weighed again for the cold carcass weight $(\mathrm{CCW})$. These values were used to determine the cold carcass yield, weight loss from cooling, and biological yield, using the previously measured EBW.

After being processed, the carcasses were used to determine the weight and yield of commercial cuts. For this evaluation, the carcasses were split lengthwise and the left half was divided into neck, shoulder, rib, loin, and leg cuts. Using a digital caliper, we took some measurements of the longissimus thoracis muscle between the 12th and 13th thoracic vertebrae, obtaining measures of the maximum muscle length $(A)$, the maximum muscle depth $(B)$, the minimum thickness of subcutaneous fat over the muscle, and the grade rule (maximum thickness of subcutaneous fat on the surface of the 13th rib at $11 \mathrm{~cm}$ from the midline, lateral to the spine). With these measurements, we calculated the loin eye area with the ellipse formula $[(A / 2 \times B / 2) \times \pi]$ (Silva Sobrinho et al. 2003).

The economic evaluation considered variations in the costs and revenues for each treatment according to the partial budget methodology (Hoffman et al. 1992). The analysis compared the current situation (Control) and alternative scenarios (other treatments) and was calculated as follows:

Net change in partial budgets $=[1+2]-[3+4]$

where 1 is the increase of revenues, 2 is the decrease of expenses, 3 is the decrease of revenues, and 4 is the increase of expenses.

In this evaluation, only fed costs were considered. Ingredient prices were obtained by quotation in the same region of animal production (northeast São Paulo State) during July to September 2015. Prices for the roughage and corn silage were obtained from Anualpec 2014 (Instituto FNP 2014). To determine the feed costs, the ingredient prices plus concentrate production costs (manufacturing process) plus roughage cost were considered.

The revenues were measured by sale of live (US $\$ 1.86 / \mathrm{kg}$ BW) or slaughtered (US $\$ 4.13 / \mathrm{kg}$ carcass) animals, where US\$1.00 equals R $\$ 3.54$ (Brazil). These values were similar to those of São Paulo State (UNICETEX, 2015) during the same period described above.
The experimental design for the four treatments was a completely randomized one ( 3 degrees of freedom). The model used was $Y_{i j}=\mu+t_{i}+e_{i j}$, where $Y_{i j}$ is the dependent variable subject to treatment $i$ and repetition $j, \mu$ is the overall mean, $t_{i}$ is the effect of the treatment, and $e_{i j}$ is the residual experimental error. When significant, the means among treatments were compared using Tukey's test with 5\% significance. The General Linear Model of the SAS software (SAS 9.1, SAS Institute Cary, NC, USA) was used.

\section{Results}

The data, Table 2, on animal performance did not differ among the treatments evaluated in this research $(P \geq 0.37)$. The same was true for the quantitative carcass characteristics $(P \geq 0.07)$. However, it was possible to consider a trend from the variable EBW results (since its $P$ value of 0.07 is close to 0.05), where treatments with CG included (CG25 and PMCG) resulted in higher EBW values than those obtained from the Control and PM20 treatments.

The commercial cuts and yields evaluated did not differ among the various biodiesel co-product treatments $(P \geq 0.09)$ (Table 3). Data collected on the longissimus thoracis muscle also did not result in significant differences $(P \geq 0.07)$. However, similar to the quantitative carcass characteristics, measurement $B(P=0.07)$ showed a trend, being shorter in the Control group (mean $2.77 \mathrm{~cm}$ ) than in the other groups fed the biodiesel co-products (mean $3.12 \mathrm{~cm}$ ).

The partial budget evaluation (Table 4) revealed that the best treatment relative to Control treatment was PM20 in both analyzed cases (i.e., sale of live and slaughtered animals). These evaluations resulted in profitability above US $\$ 2.83$ in both scenarios. The worst results were obtained with the combined inclusion of biodiesel co-products (PMCG) but were still better than those of the Control treatment.

\section{Discussion}

Animal performance was similar among the treatments evaluated (Table 2), probably due to the equal compositions of the diets ( $\mathrm{CP}, \mathrm{ME}$, and roughage-to-concentrate ratio). The diets used in this study were calculated to animal requirements for a daily gain of $300 \mathrm{~g}$ with a DMI close to $1.20 \mathrm{~kg}$ (NRC 2006). However, the DMI resulted in every treatment being below the recommended value. If considering NRC (2006) recommendations, our animals needed to consume above $3.0 \%$ of their BW. However, the results were close to $2.0 \% \mathrm{BW}$. The low DMI was likely caused by a chemotactic volume-filling effect, which occurs in diets with a high ME and low fiber composition. According to Allen (2000), a possible cause of this kind 
Table 2 Performance and quantitative carcass characteristics of lambs fed with or without biodiesel co-products finished in feedlot

\begin{tabular}{|c|c|c|c|c|c|c|}
\hline \multirow[t]{2}{*}{ Variable } & \multicolumn{4}{|l|}{ Diet } & \multirow[t]{2}{*}{ S.E.M. } & \multirow[t]{2}{*}{$P$ value } \\
\hline & Control & PM20 & CG25 & PMCG & & \\
\hline \multicolumn{7}{|l|}{ Performance } \\
\hline DMI (kg/day) & 0.69 & 0.68 & 0.70 & 0.72 & 0.02 & 0.37 \\
\hline $\mathrm{DMI}(\% \mathrm{BW})$ & 2.17 & 2.18 & 2.25 & 2.23 & 0.06 & 0.88 \\
\hline DMI (g/kg ${ }^{0.75} /$ day) & 62.74 & 64.02 & 65.90 & 65.05 & 1.70 & 0.85 \\
\hline $\mathrm{ADG}(\mathrm{kg})$ & 0.27 & 0.28 & 0.26 & 0.25 & 0.02 & 0.89 \\
\hline $\mathrm{FC}$ & 3.22 & 2.89 & 3.34 & 3.09 & 0.13 & 0.71 \\
\hline \multicolumn{7}{|c|}{ Quantitative carcass characteristics } \\
\hline SBW (kg) & 30.48 & 30.98 & 31.15 & 30.94 & 0.14 & 0.39 \\
\hline LF (kg) & 1.48 & 1.46 & 1.30 & 1.52 & 0.12 & 0.93 \\
\hline EBW (kg) & 26.04 & 26.01 & 27.56 & 26.82 & 0.25 & 0.07 \\
\hline HCW (kg) & 14.56 & 14.40 & 15.18 & 14.28 & 0.14 & 0.08 \\
\hline $\mathrm{HCY}(\%)$ & 47.82 & 46.48 & 47.91 & 46.16 & 0.44 & 0.39 \\
\hline CCW (kg) & 14.14 & 13.98 & 14.80 & 14.16 & 0.13 & 0.09 \\
\hline CWL (\%) & 2.62 & 2.54 & 2.58 & 2.60 & 0.09 & 0.99 \\
\hline CCY (\%) & 46.44 & 45.13 & 46.68 & 45.78 & 0.40 & 0.55 \\
\hline BY (\%) & 55.96 & 55.35 & 55.11 & 53.26 & 0.40 & 0.09 \\
\hline
\end{tabular}

Control: roughage + concentrate; PM20: roughage + concentrate with peanut meal 20\% DM; CG25: roughage + concentrate with crude glycerin 25\% DM; PMCG: roughage + concentrate with peanut meal $10 \%$ and crude glycerin $12.5 \% \mathrm{DM}$

S.E.M. standard error mean of filling effect is the volatile fat acid concentration (mainly acetic and propionic acids), which results in a repletion state.

If assuming that the ADG in ruminants is directly associated with their DMI, then the similarity in DMI values among the different treatments would not result in differences in the ADG values. Other critical factors causing the ADG results are the composition and nutrient value of these diets, which were close among the four treatments (CP 17\%; ME $11.3 \mathrm{MJ} /$ $\mathrm{kg}$ DM). Thus, the similarity among the feeds with or without biodiesel co-product inclusion could determine the possibility of their use for maintaining or improving animal performance.

The standard of the animals and the absence of differences in their performance were responsible for the results on the quantitative carcass characteristics. These results are important in the evaluation of new diet ingredients, because they have a high relationship with meat production and, consequently, the economic returns. Thus, since the quantitative carcass characteristics were similar among the treatments (Table 3), we can affirm that both biodiesel co-products are useable in animal feed.

The trend observed with the EBW $(P=0.07)$ could be caused by changes in the size of the gastrointestinal tract, if considering that $\mathrm{EBW}=\mathrm{SBW}-\mathrm{EGT}$, and that the diet digestibility could change the morphology of the gastrointestinal tract. CG is highly digestible owing to its chemical composition of mainly glycerol (Abughazaleh et al. 2011). In view of the fast fermentation within the rumen, this higher digestibility of CG relative to that of corn grain could cause a decrease in the size of the gastrointestinal tract, resulting in the higher EBW values in the CG25 and PMCG groups (27.56 and $26.82 \mathrm{~kg}$, respectively). The use of animals of the same age and breed can explain the absence of significance among the treatments for the commercial cuts and yield variables.

The economic evaluation, conducted independently of statistical analysis, resulted in two evident situations (Table 4). When considering diet costs, independent of units (US\$ $/ \mathrm{kg}$ DM, US\$/day, and US\$/animal), PM20 treatment consistently gave the best results, which were smaller than those of the other treatments. Basically, PM20 was $20 \%$ cheaper than the other means of treatments for these costs. With regard to the sale of these animals, both alive and slaughtered (US\$/head), the highest revenues (US\$1.68 and US\$2.89 for live and slaughtered animals, respectively) were observed with CG25 treatment.

The economic results were determined to find the better biodiesel co-product for animal feed. Considering that the animals were fed for 61 days on the feedlot, the diet costs using biodiesel co-products were less than those of the Control treatment. Of the treatments with co-product inclusion (PM20, CG25, and PMCG), the best was PM20 because the diet cost (evaluated in US\$/day) was US\$0.04 cheaper than that of the second best treatment (PMCG). This was likely because the replacement of soybean meal (US\$0.38/kg) with PM (US\$0.28/ $\mathrm{kg}$ ) results in a greater decrease of costs than 
Table 3 Commercial cuts and its yields and loin eye area (LEA) at carcasses of lambs finished in feedlot fed with or without biodiesel coproducts

\begin{tabular}{|c|c|c|c|c|c|c|}
\hline \multirow[t]{2}{*}{ Variable } & \multicolumn{4}{|l|}{ Diet } & \multirow[t]{2}{*}{ S.E.M. } & \multirow[t]{2}{*}{$P$ value } \\
\hline & Control & PM20 & CG25 & PMCG & & \\
\hline \multicolumn{7}{|c|}{ Commercial cuts and its yields } \\
\hline Neck (kg) & 0.51 & 0.51 & 0.58 & 0.52 & 0.02 & 0.32 \\
\hline $\operatorname{Neck}(\%)^{1}$ & 7.25 & 7.38 & 8.05 & 7.37 & 0.19 & 0.49 \\
\hline Shoulder (kg) & 1.60 & 1.57 & 1.63 & 1.54 & 0.02 & 0.46 \\
\hline Shoulder $(\%)^{1}$ & 22.78 & 22.58 & 21.56 & 21.88 & 0.24 & 0.27 \\
\hline Ribs (kg) & 1.66 & 1.63 & 1.80 & 1.70 & 0.04 & 0.36 \\
\hline $\operatorname{Ribs}(\%)^{1}$ & 23.57 & 23.44 & 24.82 & 23.24 & 0.25 & 0.09 \\
\hline Loin (kg) & 0.91 & 0.82 & 0.88 & 0.88 & 0.02 & 0.59 \\
\hline Loin $(\%)^{1}$ & 12.91 & 11.77 & 12.09 & 12.46 & 0.26 & 0.48 \\
\hline $\operatorname{Leg}(\mathrm{kg})$ & 2.36 & 2.39 & 2.35 & 2.40 & 0.02 & 0.84 \\
\hline $\operatorname{Leg}(\%)^{1}$ & 33.51 & 34.38 & 32.46 & 34.11 & 0.34 & 0.19 \\
\hline \multicolumn{7}{|l|}{ Loin eye area } \\
\hline $\mathrm{A}(\mathrm{cm})$ & 5.11 & 5.37 & 5.63 & 5.52 & 0.08 & 0.08 \\
\hline $\mathrm{B}(\mathrm{cm})$ & 2.77 & 3.02 & 3.24 & 3.10 & 0.07 & 0.07 \\
\hline Area $\left(\mathrm{cm}^{2}\right)$ & 11.12 & 12.75 & 13.81 & 13.47 & 0.43 & 0.11 \\
\hline SFT (mm) & 2.52 & 2.14 & 2.91 & 2.30 & 0.15 & 0.29 \\
\hline GR (mm) & 5.25 & 5.04 & 6.56 & 5.54 & 0.24 & 0.09 \\
\hline
\end{tabular}

Control: roughage + concentrate; PM20: roughage + concentrate with peanut meal 20\% DM; CG25: roughage + concentrate with crude glycerin 25\% DM; PMCG: roughage + concentrate with peanut meal $10 \%$ and crude glycerin $12.5 \% \mathrm{DM}$

S.E.M. standard error mean

${ }^{1}$ Data were analyzed after transformation: arcscene*[square root (\%value/100)]

those resulting from the replacement of corn grain (US\$0.17/ $\mathrm{kg}$ ) with CG (US\$0.09/kg). Although PM20 reduced the diet costs, this treatment was not better in terms of revenues. Considering the two revenue sources, from specific data found in this study, the best treatment was CG25. The main cause of these higher revenues was the low LF, which resulted in higher EBW and consequently higher $\mathrm{CCW}$ values, measurements associated with the sale price. Therefore, after accounting for revenues, we calculated the net change of partial budgets by comparing the PM20, CG25, and PMCG treatments with the Control treatment (considered standard). The economic results showed positive values for all three biodiesel co-product treatments, indicating them to be better than the Control treatment. However, the best of the three treatments was PM20 because of its higher values in both sales of live and slaughtered animals. Thus, in concordance with the study of Barros et al. (2015), we observed the benefits of using biodiesel co-products in animal feed. However, prior to recommending the use of these new ingredients, a key point is to ensure standardization of these products sold by the agroindustry.
Table 4 Economic evaluation and partial budgets resulting of lamb production fed with or without biodiesel co-products finished in feedlot

\begin{tabular}{lllll}
\hline Variable & \multicolumn{1}{l}{ Diet } & & & \\
\cline { 2 - 5 } & Control & PM20 & CG25 & PMCG \\
\hline Economic evaluation ${ }^{1}$ & & & & \\
Diet cost (US\$/kg DM) & 0.44 & 0.36 & 0.43 & 0.41 \\
Diet cost (US\$/day) & 0.31 & 0.25 & 0.30 & 0.29 \\
Diet cost (US\$/animal) & 18.62 & 14.96 & 18.42 & 17.95 \\
Revenues source (US\$/head) & & & \\
Live animal & 56.74 & 57.67 & 59.02 & 57.60 \\
Slaughtered & 58.45 & 57.76 & 61.14 & 58.52 \\
Partial budgets (US\$/head) & & & & \\
& Diet-control & & & \\
& PM20 & & CG25 & PMCG \\
$\mathrm{NC1}^{3}$ & 4.59 & & 2.47 & 1.52 \\
$\mathrm{NC}^{4}$ & 2.97 & & 2.88 & 0.74 \\
\hline
\end{tabular}

Control: roughage + concentrate; PM20: roughage + concentrate with peanut meal 20\% DM; CG25: roughage + concentrate with crude glycerin 25\% DM; PMCG: roughage + concentrate with peanut meal $10 \%$ and crude glycerin $12.5 \% \mathrm{DM}$

${ }^{1}$ Ingredient costs (US $\left.\$ / \mathrm{kg} D M\right)$ : corn silage US $\$ 0.07$; corn grain US $\$ 0.17$; soybean meal US $\$ 0.38$; glycerin US $\$ 0.09$; peanut meal US\$0.28; mix US\$0.58

${ }^{2}$ Subtraction between costs of diet testing and Control diet

${ }^{3}$ Net change of partial budgets - live animal sale

${ }^{4}$ Net change of partial budgets - slaughtered animal sale

In summary, in this scenario, PM and CG added alone or in combination into the lamb diet did not change the DMI and consequently did not alter the animal performance and quantitative carcass characteristics. Because they are cheaper than traditional ingredients, biodiesel co-products, especially PM, would result in better economic results.

Funding information The authors thank São Paulo Research Foundation (FAPESP; grant \#2013/23495-5) for providing financial support. E.P. Romanzini received a scholarship from the National Council of Technological and Scientific Development (CNPq; grant \#131978/20144). R.L. Valença received a scholarship from the Brazilian Federal Coordination of Higher Education (CAPES). T.H. Borghi and P.A. Bernardes received a scholarship from FAPESP (grants \#2012/25250-7 and \#2013/09364-5, respectively). N. Andrade received a scholarship from CNPq (grant \#142283/2014-2).

\section{Compliance with ethical standards}

Statement of animal rights All applicable international, national, and or institutional guidelines for the care and use of animals were followed. The protocol used in this experiment was in accordance with the National Council for Animal Experiments Control (CONCEA) guidelines and was approved by the Ethics Committee on Animal Use (CEUA) of FCAVUnesp/Jaboticabal Campus (Protocol \#022014/13).

Conflict of interest The authors declare that they have no conflicts of interest. 


\section{References}

Abughazaleh, A.A., Abo El-Nor, S. and Ibrahim, S.A., 2011. The effect of replacing corn with glycerol on ruminal bacteria in continuous culture fermenters. Journal of Animal Physiology and Animal Nutrition, 95, 313-319.

Allen, M.S., 2000. Effects of diet on short-term regulation of feed intake by lactating dairy cattle. Journal of Dairy Science, 83, 1598-1624.

AOAC, 1995. Official Methods of Analysis of AOAC International, 16th edition, (Association of Official Analytical Chemists, Arlington, TX).

Barros, M.C.C., Marques, J.A., Silva, F.F., Silva, R. R., Guimarães, G.S., Silva, L.L. and Araújo, F.L., 2015. Glicerina bruta na dieta de ovinos confinados: consumo, digestibilidade, desempenho, medidas morfométricas da carcaça e características da carne. Semina Ciências Agrárias, 36, 453-466.

Castro, D.P.V., Yamamoto, S.M., Araújo, G.G.L., Pinheiro, R.S.B., Queiroz, M.A.A., Albuquerque, I.R.R. and Moura, J.H.A., 2017. Influence of drinking water salinity on carcass characteristics and meat quality of Santa Inês lambs. Tropical Animal Health and Production, 49, 1095-1100.

Ezequiel, J.M.B., Sancanari, J.B.D., Machado Neto, O.R., da Silva, Z.F., Almeida, M.T.C., Silva, D.A.V., van Cleef, F.O.S. and van Cleef, E.H.C.B. 2015. Effects of high concentrations of dietary crude glycerin on dairy cow productivity and milk quality. Journal of Dairy Science, 98, 1-9.

Goering, H.K. and Van Soest, P.J., 1970. Forage Fiber Analyses, (USDA, Washington, DC).

Hoffmann, R., Engler, J.J.C., Serrano, O., Thame, A.C.M. and Neves, E.M., 1992. Administração da Empresa Agrícola, (Pioneira, São Paulo).

Instituto FNP, 2014. Anualpec 2014: Anuário da Pecuária Brasileira, (Instituto FNP, São Paulo)
Merlim, F.A., Silva Sobrinho, A.G., Borghi, T.H., Zeola, N.M.B.L., Cirne, L.G.A., Romanzini, E.P., Andrade, N. and Almeida, F.A., 2015. Ile de France lambs fed diets containing glycerin: characteristics of carcass and commercial cuts. Journal of Agricultural Engineering and Biotechnology, 3, 79-83.

Myers, S.S., Smith, M.R., Guth, S., Golden, C.D., Vaitla, B., Mueller, N.D., Dangour, A.D. and Huybers, P., 2017. Climate change and global food systems: potential impacts on food security and undernutrition. Annual Reviews Public Health, 38, 259-277.

NRC (National Research Council) 2006. Nutrients Requirements of Sheep, (National Academy Press, Washington, DC).

Oliveira, J.S., Antoniassi, R., Freitas, S.C. and Muller, M.D., 2013. Composição química da glicerina produzida por usinas de biodiesel no Brasil e potencial de uso na alimentação animal. Ciência Rural, 43, 509-512.

Ružić-Muslić, D., Petrović, M.P., Petrović, M.M., Bijelić, Z., CaroPetrović, V., Maksimović, N. and Mandić, V., 2014. Protein source in diets for ruminant nutrition. Biotechnology in Animal Husbandry, 30, 175-184.

Silva Sobrinho, A.G., Kadim, I.T. and Purchas, R.W., 2003. Effect of genotypes and age on carcass and meat quality characteristics of ram lambs. Agriculture Marine Science, 8, 73-78.

Sniffen, C.J., O'Connor, J.D., Van Soest, P.J., Fox, D.G. and Russell, J.B., 1992. A net carbohydrate and protein system for evaluating cattle diets. II. Carbohydrate and protein availability. Journal of Animal Science, 70, 3562-3577.

UNICETEX. Informativo semanal do indicador de preço do cordeiro paulista-Setembro/2015. Centro de Inovação, Empreendedorismo e Extensão Universitária, 2015. http://media.wix.com/ugd/2ad832 abde39c319b54ef3b65b3fa5f119a67f.pdf. Accessed 4 Oct 2015

Van Soest, P.J., 1994. Nutritional Ecology of the Ruminant, (Cornell University Press, Ithaca, NY). 